bring before you a somewhat difficult case which occurred in my practice last year. The patient was a young woman of the hysterical temperament, who on becoming insane persistently refused every kind of food. At first spoonfeeding by attendants was resorted to, and answered every purpose; but this process soon failed, and after a prolonged abstinence, the pulse becoming very small and feeble, I determined to feed with the storuach-tube. I usually employ a small key to open the mouth with (which can be obtained at Maw's), which invariably proves a most serviceable instrument. On this occasion, however, the patient firmly clenched her teeth, and they were so white and strong, and fitted so beantifully, that I was unable to find a single crevice in to which $I$ could insert the point of the key. The next attempt to open them was made with a thin teaspoon, which I endeavoured to introduce between the teeth, but again unsuccessfully. I should, perhaps, mention here that the patient was laid on her back and held down in the manner recommended by Dr. Williams, of Hayward's Heath. I next poured some beef-tea into the mouth, hoping it would find its way down the throat behind the teeth. This simple proceeding unexpectedly produced the desired effect. The patient coughed, choked, and spat out the whole of the fluid, but in doing so I observed that she opened her mouth and also her teeth to gasp for breath. On repeating the pouring in of the liquid the same thing occurred again, and being this time prepared for it, I thrust in the key, opened the mouth with it, passed the tube, and fed the patient comfortably.

I believe that a patient may reject almost every drop of liquid food, by coughing and spitting it up, if fed with the spoon only, and I also believe that there are cases in which the teeth are so strong and regular, and in which the jaw is so powerful, that nothing short of injuring one of the teeth would open the mouth, if force only were to be relied on; but I do not believe that the most determined ratient, provided he was laid on his back, could resist being fed by the method described above. The patient is simply in a dilemma: he must either swallow the liquid or cough it out, and in doing so it is almost impossible for him to avoid slightly opening the mouth. When this is accomplished, the rest of the proceeding is easy enough.

I am, Sir, your obedient servant,

H. Sutherliand.

Richmond-terrace, Whitehall, January 11th, 1873.

\section{REFLEC'TIONS ON THE POSSIBLE MOTIVES FOR THE CORAM-STREET MURDER.}

To the Editor of The Lancet.

Sir,-Various surmises have been hazarded as to the motives for the late murder of the unfortunate woman in Great Coram-street. Some surprise has been expressed at the opinion I have given, that revenge or vengeance is the most probable cause, and $I$ have been asked to give the reasons which influence me in coming to this conclusion.

In the early part of my professional career, when investigating the causes of contagion, in association with the late Drs. Read and Fitzgerald, I examined a woman murdered by a man named Connor-a case which at the time caused as much public sensation as has this Coramstreet assassination. In the instance $I$ am speaking of the case was known as the St. Giles's murder, and it was proved that her paramour cut the woman's throat because she had given him a disease under which he then suffered, and which the post-mortem proved she was afflicted with at the time of her death. Subsequent experience has taught me that there are exceptional men in all ranks of society, so morbidly constituted that, when suffering under contagious aisease (the result of a dissipated life), they are ready to wreak their vengeance on the individual female who has, or is supposed to have, been the cause of their ailment. I have even known these over-wrought brains brooding for dass over their misery, and, failing to discover the true culprit, threaten to avenge themselves on the first woman they met who they had reason to suppose would knowingly communicate disease to those having relations with them. Other practitioners must doubtless have met with men thus morbidly sensitive, and who in the prosecution of their revenge would not scruple to murder one who is supposed to have no friends. Indulgent confrères will recollect consultations held upon cases where the present symptoms are by patients attributed to a disease supposed to have been contracted years ago, and which my own assertions, as well as those of the family physician, will for a time allay. Such malades imaginaires return again and again to the charge, characterising a phase of life not depicted in the Rake's Progress. I fully believe that the increasing number of undetected murders in London may be attributed to some such cause.

While on the subject of these women I would call the attention of my professional brethren to the deplorable state of morals brought to light by the publication of this Coram-street murder. It but corroborates the daily police reports, as well as the statements to which I called public attention in my paper before the Social Science Association at Plymouth. I have every reason to believe that the women called in the police reports "fast," "gay," and "unfortunate" actually live in some of the most respectable streets, and associate in lodgings with moral young men living in the house; and, further, are the companions of married women who wilfully pretend to ignore the way such well-dressed and lady-like fellowlodgers gain their livelihood. The landladies, moreover, tacitly connive at their immorality as long as their lodgers earn plenty of money and spend it freely. They only exact that appearances should be kept up for the sake of what they call "the respectability of the house." Recent police reports have corroborated what I have long ago called public attention to-viz., that indiscriminate parish prosecutions of houses of ill-fame have driven the inmates to employ all sorts of subterfuges to obtain lodgings. There can be no doubt (regret it as we may) that the efforts of these well-intentioned but ill-informed associations of worthy men have caused these women, in collusion with men of property, to convert some of the largest botels in London and environs, as well as the coffee-houses in many of the principal streets, in to mere "accommodation houses." At the present moment these associations, whose motives are excellent but whose experience is limited, are carrying out in London a system of repression which bas completely failed in Berlin, where repeated raids on houses of ill-fame have been proved to be so injurious to public morals that in the Prussian capital houses are now tolerated by the Government merely to prevent even worse forms of evil springing up. Are we not drifting into the same position? The late Royal Commission on the Contagious Diseases Acts acknowledged that "prostitution was a great fact." My belief is, that it is Quixotic to suppose that a small section of society can, by indicting bad houses, put an end to the evil; but I am equally convinced that we may do much to ameliorate some of its worst effects. Experience leads me to believe that the police authorities, not parishes or associations of private individuals, sbould indict houses of ill-fame. We should then cease to find a repetition of this Coram-street scandal.

I am, Sir, your obedient servant,

Queen Anne-street, Jan. 1873.

W. ACTON.

\section{TREATMENT OF EPISTAXIS.}

\section{To the Editor of The Lancet.}

Sin,-I was very pleased to see the letter of Dr. Taaffe in The Lancet of Jan. 4th, as I feared that the subject on which he writes might drop, and that my object in drawing the attention of the profession to an operation which, althongh a small one, I think I may designate as barbarous and certainly requiring some alteration, might fail.

All who have had to treat many cases of epistaxis will, I think, agree with me that rather than resort to plugging the posterior nares, as at present performed, we are only t 30 apt to temporise with the dificulty, using inefficient means, day after day, which never place the patient in a state of safety, and leave ourselves in a constant state of anxiety lest we should be summoned again at any moment. The patient, mean while, keeps losing blood which, if elderly, and, as generally happens in cases which are the most troublesome, the subject of visceral disease, he is ill able to spare.

What we want is some small handy instrument that we 